\title{
RBL2 wt Allele
}

National Cancer Institute

\section{Source}

National Cancer Institute. RBL2 wt Allele. NCI Thesaurus. Code C51299.

Human RBL2 wild-type allele is located in the vicinity of $16 q 12.2$ and is approximately 57

$\mathrm{kb}$ in length. This allele, which encodes retinoblastoma-like protein 2 , is involved in cell

cycle regulation and cellular proliferation mediation. 